\title{
Development of Hydrothermal and Frictional Experimental Systems to Simulate Sub-seafloor Water-Rock-Microbe Interactions
}

\author{
Katsuhiko Suzuki, Shingo Kato, Takazo Shibuya, Takehiro Hirose, \\ Shigshi Fuchida, V.J Rejish Kumar, Motoko Yoshizaki, Yuka Masaki, \\ Kentaro Nakamura, Kensei Kobayashi, Harue Masuda, Akihiko Yamagishi, \\ and Tetsuro Urabe
}

\begin{abstract}
Since the discovery in 1977 of deep-sea hydrothermal vents, they have been shown to host unique but diverse biological communities, despite the dark, barren ocean-floor settings in which they exist. Recent research has indicated that the production by fault systems of abundant reducing agents such as hydrogen possibly sustains the microbial communities in these chemoautotrophic ecosystems. High-pressure and high-temperature hydrothermal experiments, and friction experiments, have resulted in the development of important new experimental apparatuses. A batch-type (closed) experimental system that creates
\end{abstract}

K. Suzuki $(\bowtie)$

Institute for Research on Earth Evolution (IFREE), Japan Agency for Marine-Earth Science and Technology (JAMSTEC),

2-15 Natsushima, Yokosuka 237-0061, Japan

Precambrian Ecosystem Laboratory, Japan Agency for Marine-Earth Science and Technology (JAMSTEC), 2-15 Natsushima, Yokosuka 237-0061, Japan

Seafloor Resources Research Project (SRRP), Japan Agency for Marine-Earth Science and Technology (JAMSTEC), 2-15 Natsushima, Yokosuka 237-0061, Japan e-mail: katz@jamstec.go.jp

\section{S. Kato}

Japan Collection of Microorganisms, RIKEN BioResource Center, 3-1-1 Koyadai, Tsukuba, Ibaraki 305-0074, Japan

Department of Molecular Biology,

Tokyo University of Pharmacy and Life Science,

1432-1 Horinouchi, Hachioji,

Tokyo 192-0392, Japan

\section{T. Shibuya}

Precambrian Ecosystem Laboratory, Japan Agency for Marine-Earth Science and Technology (JAMSTEC),

2-15 Natsushima, Yokosuka 237-0061, Japan

Seafloor Resources Research Project (SRRP), Japan Agency for Marine-Earth Science and Technology (JAMSTEC), 2-15 Natsushima, Yokosuka 237-0061, Japan

\section{T. Hirose}

Kochi Institute for Core Sample Research, Japan Agency for Marine-Earth Science and Technology (JAMSTEC), 200 Monobe-otsu, Nankoku, Kochi 783-8502, Japan

\section{S. Fuchida $\bullet$ H. Masuda}

Department of Geosciences, Osaka City University,

3-3-138, Sugimoto Sumiyoshi-ku, Osaka 558-8585, Japan

V.J Rejish Kumar • A. Yamagishi

Department of Molecular Biology,

Tokyo University of Pharmacy and Life Science,

1432-1 Horinouchi, Hachioji,

Tokyo 192-0392, Japan

M. Yoshizaki

Precambrian Ecosystem Laboratory, Japan Agency

for Marine-Earth Science and Technology (JAMSTEC),

2-15 Natsushima, Yokosuka 237-0061, Japan

Department of Earth and Planetary Sciences, Tokyo Institute of Technology, 2-12-1 Ookayama, Meguro-ku,

Tokyo 152-8551, Japan

Y. Masaki

Institute for Research on Earth Evolution (IFREE), Japan Agency

for Marine-Earth Science and Technology (JAMSTEC),

2-15 Natsushima, Yokosuka 237-0061, Japan

Seafloor Resources Research Project (SRRP), Japan Agency

for Marine-Earth Science and Technology (JAMSTEC),

2-15 Natsushima, Yokosuka 237-0061, Japan

K. Kobayashi

Graduate School of Engineering, Yokohama National University, 79-5 Tokiwadai, Hodogaya-ku, Yokohama, Kanagawa 240-8501, Japan

T. Urabe

Department of Earth and Planetary Science,

The University of Tokyo, 7-3-1 Hongo, Bunkyo-ku,

Tokyo 113-0033, Japan

K. Nakamura

Department of Systems Innovation, The University of Tokyo, 7-3-1

Hongo, Bunkyo-ku, Tokyo 113-8656, Japan 
equilibrium conditions has contributed greatly to our understanding of sub-seafloor hydrothermal reactions. Flow-type experimental systems have allowed investigation of natural systems under non-equilibrium conditions. Friction experiments have recently been developed to better understand generation of the hydrogen that makes fault systems habitable by primary producers. These experiments suggest that microbial ecosystems sustained by chemical energy derived from fault systems might be widely distributed within oceanic crust. Moreover, flow-type systems that can be used to simulate natural hydrothermal environments that include crustal aquifers might provide insights into the ecological significance of microorganisms and their global contribution to biogeochemical cycles in the ocean and crust.

Here we describe hydrothermal and friction experiment systems that we developed during our Trans-crustal Advection and In-situ biogeochemical processes of Global subseafloor Aquifer (TAIGA) project, and consider the application of some of them to explore the interactions among rocks, fluids, and microbes. For this purpose, our original data obtained in the experiment of interaction between basalt and water in the flow-type system was also included.

Keywords

Friction experiment • Hydrothermal experiment

\subsection{Introduction}

Hydrothermal experiments using a gun barrel were first undertaken in the 1850s. These experiments determined the solubilities of minerals and investigated their growth mechanisms. Since then, researchers on ore genesis have used experimental apparatuses to investigate the alteration of wall rocks and its relation with hydrothermal gold mineralization.

Hydrothermal interactions between seawater and the lithosphere strongly influence the chemistry of the oceans and control heat exchange between the lithosphere and hydrosphere (Alt 1995). The discovery of deep-sea hydrothermal vents at the Galapagos Spreading Center in 1977 (Corliss et al. 1979; Spiess et al. 1980) inspired much interest in deep-sea hydrothermal systems from scientists in various fields. Gold proposed that microbial ecosystems are widely distributed in sub-seafloor aquifers (Gold 1992). The existence of sub-seafloor ecosystems has been verified by biochemical analyses of samples collected during deep oceanfloor drilling (Cowen et al. 2003; Kimura et al. 2003; Higashi et al. 2004; Nakagawa et al. 2004; Hara et al. 2005; Huber et al. 2006). These studies have shown that hydrothermal vents and deep sea low-temperature springs host diverse biological communities that are sustained by the production of reducing agents such as hydrogen, methane, sulfur, and iron (the TAIGA systems; see Chap. 1), despite the dark, barren ocean-floor settings in which they live (Kelley et al. 2005; Nealson et al. 2005; Takai et al. 2006). These chemoautotrophs obtain energy from the chemical potential between reducing agents in hydrothermal/spring solutions and oxidizing seawater.
Although various types of hydrothermal fluids with different chemistries issue from the ocean floor (Kelley et al. 2005), such fluids in abyssal hydrothermal systems have been proposed as nurturers of the earliest microbial ecosystems. The Rainbow and Kairei fields on the Central Indian Ridge are extremely enriched in $\mathrm{H}_{2}$ (Takai et al. 2004; Gallant and Von Damm 2006; Kumagai et al. 2008) and host a phylogenetically primitive ecosystem (Yanagawa and Kojima 1985; Russell and Hall 1997). However, because opportunities for investigative cruises have been limited, laboratory experiments have been used effectively to considerably increase our knowledge of the chemistry of hydrothermal vents. An advantage of an experimental approach is that it allows examination of the processes and interactions among hydrothermal solutions, rocks, fault systems, organic matter, and microbial communities by simulating the hydrothermal conditions beneath the seafloor. However, simulating the physical and chemical conditions of seafloor hydrothermal systems in the laboratory is challenging (Seewald 1994; Seyfried et al. 1998). Hydrothermal experiments must be designed to withstand high fluid pressures (up to $50 \mathrm{MPa}$ ) and permit temporal monitoring of changes in the composition of fluids coexisting with complex mineral assemblages over a wide range of reaction temperatures. Closed batch-type experimental systems have been used to simulate hydrothermal conditions for several decades (Thornton and Seyfried 1987; Seyfried and Ding 1993), and flow-through systems have more recently been designed to study this environment (Normand et al. 2002).

In 2008, we commence the multi-disciplinary TAIGA (Trans-crustal Advection and In-situ biogeochemical 
processes of Global sub-seafloor Aquifer) project, which focuses on interactions among the lithosphere, hydrosphere, and biosphere by examining fluid circulation systems beneath the seafloor. TAIGA is a multi-disciplinary project that uses geophysics (to investigate crustal structure), petrology, geochemistry, microbiology, and laboratory experiments. During the TAIGA project, we developed various experimental systems. In this review, we discuss those apparatuses and others used in hydrothermal and friction experiments, and consider the application of some of them to reveal mechanisms of interaction among rocks, fluids, and microbes. Hydrothermal and frictional experimentation is very much dependent on the development of new experimental apparatuses and techniques, which have been used to achieve successful simulations of various sub-surface conditions in hydrothermal and fault systems. We first describe the two types of apparatus that have been used in hydrothermal experiments (closed batch-type and flowthrough devices) and then describe the frictional experiment (simulated fault) system.

\subsection{Hydrothermal Experimental Apparatus}

\subsubsection{Batch-Type Systems}

The first known hydrothermal experiment was conducted using a gun barrel (Sénarmont 1851). Typical modern hydrothermal apparatuses are the cold-seal type developed by Tuttle $(1948,1949)$ and an apparatus developed by Morey and Ingerson (1937) and Morey (1942). Tuttle's cold-seal autoclave had a small reaction cell (less than a few tens of milliliters) with a seal outside the furnace (cold seal), and it could be used at temperatures up to $1,200{ }^{\circ} \mathrm{C}$ and pressures of 100-200 MPa. The autoclave designed by Morey and co-workers had a larger cell (more than $250 \mathrm{~mL}$ ), with metal packing and a Bridgeman seal (Bridgeman 1949), and it could be used at temperatures above $400{ }^{\circ} \mathrm{C}$. An autoclave with an even larger volume (up to $1,000 \mathrm{~mL}$ ) and a flat flange seal designed by Barnes $(1963,1971)$ was equipped with a rocking system to promote the rock-water reaction and used the first, simple in situ sampling system. This system was frequently used for experiments on alteration of rocks during investigations of ore genesis.

\subsubsection{Dickson-Type Autoclave}

Dickson et al. (1963) designed the autoclave that is most commonly used today, and significant progress has been made in hydrothermal experiments using it. The Dicksontype autoclave is made of Inconel alloy, which is corrosion resistant and retains adequate strength at elevated temperatures and pressures. We used a Dickson-type autoclave in our TAIGA project at the Japan Agency for Marine-
Earth Science and Technology (JAMSTEC) to reproduce hydrothermal conditions of up to $600{ }^{\circ} \mathrm{C}$ and $60 \mathrm{MPa}$. One of the characteristics of the Dickson-type apparatus is that it has a flexible reaction cell in the metal autoclave (Fig. 7.1) that allows in situ sampling of reacted solutions without a significant decrease in the pressure within the cell. Though the flexible cell gradually shrinks when sample solution is removed, a pump provides a small continuous flow of pressurized water within the autoclave to maintain the pressure and temperature. Another advantage of the Dickson-type apparatus is that the metal autoclave is isolated from corrosive high-salinity reaction water. These features have allowed researchers to make considerable progress in understanding deep-sea hydrothermal systems (e.g., Berndt et al. 1996; Seyfried et al. 1998, 2007; McCollom and Seewald 2001, 2003a, b, 2007; Yoshizaki et al. 2009; Shibuya et al. 2013). Because the reaction cell of the initial system was made of Teflon (Dickson et al. 1963), the experiment could only be performed at temperatures of less than $285^{\circ} \mathrm{C}$, too cold to reproduce high-temperature hydrothermal reactions. A thin gold bag was later used for the reaction cell (Rytuba et al. 1978), but it was difficult to seal the sample and solution in the bag without creating a pin hole. The use of a Ti head on the gold bag markedly improved the Dickson-type hydrothermal experimental system (Seyfried et al. 1979; Seyfried 1987) (Fig. 7.2). Because titanium oxide is resistant to corrosion by seawater, the surface of the Ti head is deliberately oxidized before experimental use to avoid production of abundant $\mathrm{H}_{2}$ by the reaction of Ti metal with seawater. Fluid samples can be extracted from the reaction cell through a gold-lined tube at any time during an experiment. The gold tube is inserted into a stainless steel or Inconel tube, and both ends of the gold tube are then expanded by heating with a torch such that they cover the ends of the stainless steel or Inconel tube (Fig. 7.3). To eliminate organic matter that will react with hydrogen to produce methane, all of the materials that will come into contact with the reaction fluid during the experiment are baked in a muffle furnace at $500{ }^{\circ} \mathrm{C}$ for $3 \mathrm{~h}$ before use.

We used a batch-type system at JAMSTEC to reproduce a komatiite hydrothermal system. We first synthesized komatiite in a redox-controlled furnace (e.g., Yoshizaki et al. 2009) and then pulverized the komatiite before placing it in our experimental apparatus. Abundant hydrogen was produced by the reaction of the komatiite with artificial seawater at $350{ }^{\circ} \mathrm{C}$ and $50 \mathrm{MPa}$ (Yoshizaki et al. 2009). We also conducted water-rock reaction experiments in the presence of $\mathrm{CO}_{2}$ in a Dickson-type system (Shibuya et al. 2013). The reaction solution was a mixture of $\mathrm{NaHCO}_{3}$, $\mathrm{NaCl}, 36 \% \mathrm{HCl}$, and pure water. To avoid degassing of $\mathrm{CO}_{2}$ by reaction of $\mathrm{NaHCO}_{3}$ and $\mathrm{HCl}$ before the reaction cell was sealed, the $\mathrm{NaHCO}_{3}$ and $\mathrm{HCl}$ were separately 


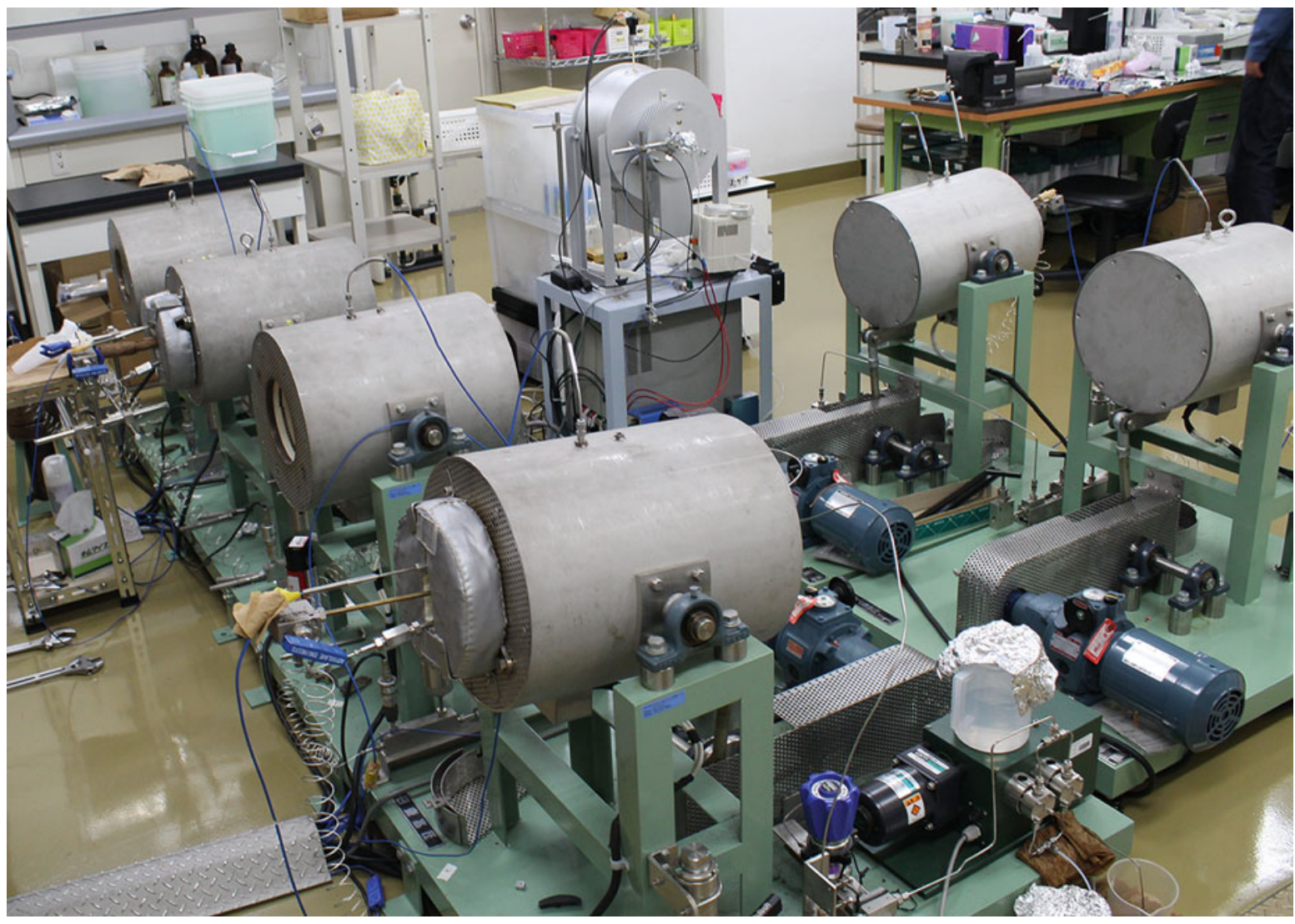

Fig. 7.1 Photo of Dickson-type autoclaves at JAMSTEC

loaded into the bottom and top, respectively, of the reaction cell in addition to the basalt powder and $\mathrm{NaCl}$ solution being loaded into the bottom. After the reaction cell was sealed, it was shaken to dissolve and completely mix these reagents.

\subsubsection{Batch Experiments to Investigate Amino Acid Reactions During Interactions of Sediments and Hydrothermal Solutions}

To investigate the reactions of amino acids under deep-sea hydrothermal conditions, we designed two batch-type autoclave reactors at Osaka City University. The first type used a Teflon jar as the reaction vessel $(25 \mathrm{~mL})$ within a stainless steel autoclave. A Teflon reaction vessel was chosen for ease of handling and because it would not react with the reaction fluids, but this choice limited the maximum reaction temperature to $200{ }^{\circ} \mathrm{C}$. The system was not equipped with an in situ sampling system; reacted samples were collected after the experiment.

The second batch-type autoclave used a titanium reaction vessel and lid (volume $160 \mathrm{~mL}$ ) with an in situ sampling system (Fig. 7.4) that allowed sampling of the solution during the experiment. After a sample was placed in the vessel, argon gas was flushed through the system to prevent oxidation, and the vessel was tightly closed and heated by a mantle heater to a maximum temperature of $300{ }^{\circ} \mathrm{C}$. Gold mesh in the head of the sampling valve was used to prevent contamination of the collected liquid phase by solids. The temperature of the reactor was controlled and monitored with a thermocontroller. Solutions were collected from the reactor at predetermined time intervals without reducing the temperature of the reactor vessel.

Reactors such as those described above provide a means to observe dissolution of organic and inorganic matter from rocks and sediments under various hydrothermal conditions. These experimental systems have been used to observe the behavior and dissolution processes of amino acids during reactions between $\mathrm{NaCl}$ solutions and natural seafloor sediments (Ito et al. 2006, 2009). Ito and co-workers reported that amino acids were rapidly released from the sediments and were then gradually decomposed in hydrothermal solution at temperatures above $150{ }^{\circ} \mathrm{C}$. Reactors such as these enable observation under hydrothermal conditions of the kinetic behavior and the stability of organic matter such as amino acids, peptides, and proteins. For example, comparison of the effect of heating of six amino acids (Glycine, Serine, Glutamate, Lysine, Cysteine, and Proline) under acidic and alkaline hydrothermal conditions at $150{ }^{\circ} \mathrm{C}$ for $3-168 \mathrm{~h}$ indicated that amino acids are 
Fig. 7.2 Photos of Dickson-type hydrothermal system showing detail views of gold sample cell with Ti lid
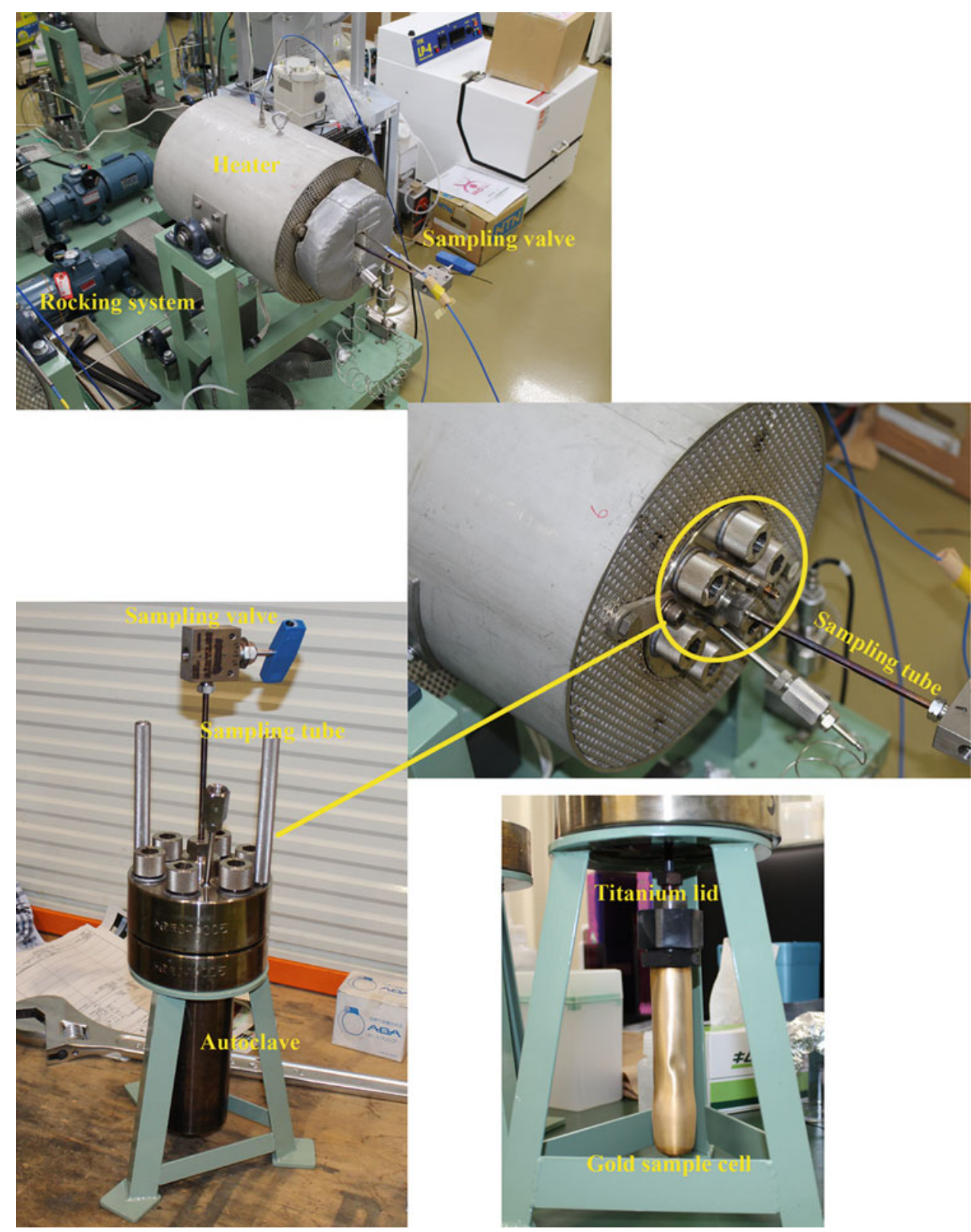

kinetically less stable under acidic conditions than under alkaline conditions (Ito et al. 2006, 2009).

\subsubsection{Flow-Type Systems}

The advantage of flow-type systems over batch-type systems is that they better simulate the water-rock interactions of natural hydrothermal systems. In batch-type systems, the chemical composition and $\mathrm{pH}$ of the reaction solution change with time, whereas flow-type systems allow these parameters to remain constant during an experiment.

A flow-type system was first designed in the 1950s, as described by Williams-Jones et al. (1994). A simple, single- path flow-type apparatus for measuring the solubility of various minerals was designed for use in experiments on the alteration of minerals during hydrothermal ore genesis (Morey and Hesselgesser 1951; Morey and Chen 1955; Morey and Fournier 1961). Other researchers have used this single-path system to measure the solubility of magnetite, $\mathrm{NiO}$, and $\mathrm{UO}_{2}$ (Seweeton and Baes 1970; Tremaine and Leblanc 1980; Tremaine et al. 1981), to determine the mobility of uranium in felsic volcanic rocks (Zielinski 1979), and to analyze serpentinization (Barnes et al. 1972). A circulation path flow-type experimental system, which was first designed by Barnes et al. (1983), has been used in kinetic studies of mineral-water interactions (Charles and Bayhurst 1983; Barnes and Gould 1992). 


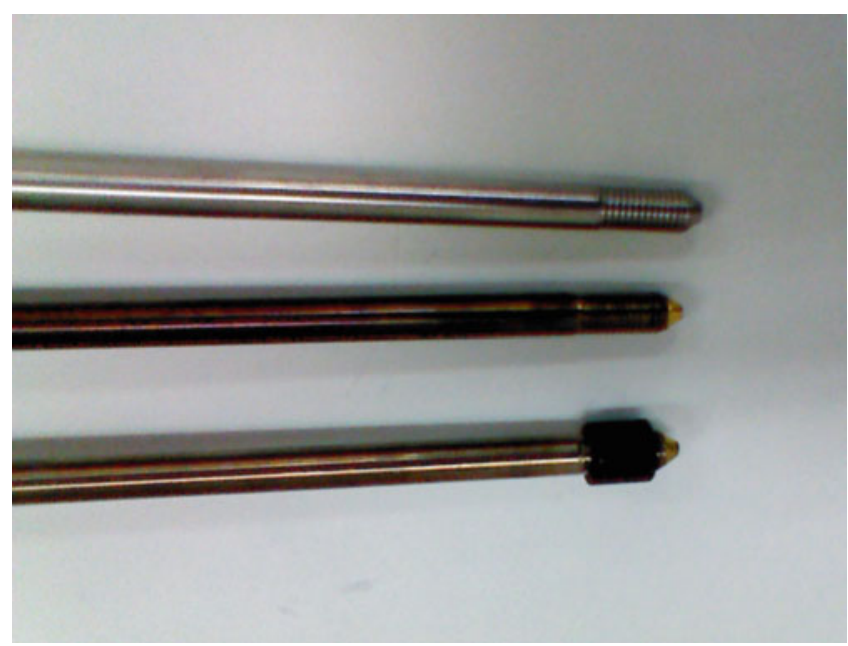

Fig. 7.3 Photo of sampling tube with gold liner

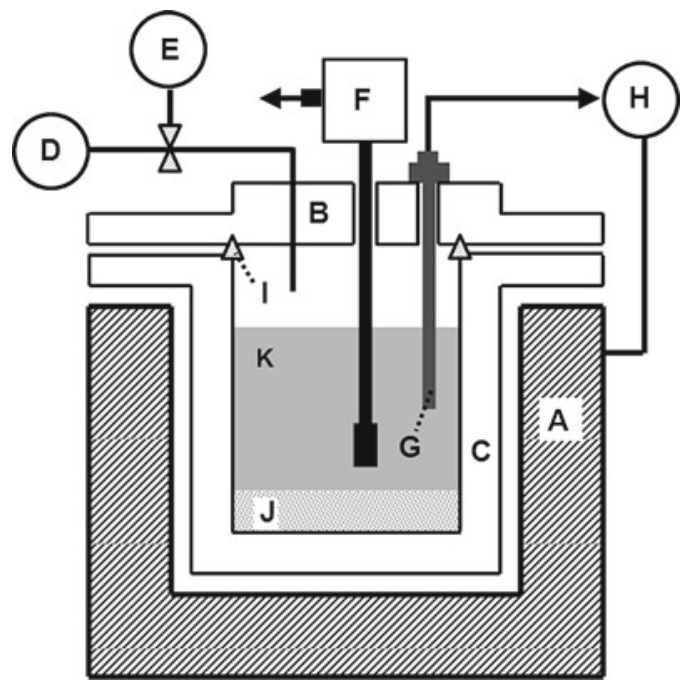

A: Mantle heater, B: Lid, C: Reaction vessel,

D: Argon gas cylinder, E: Pressure gauge,

F: Sampling valve, G: thermocouple,

H: Controller and Recorder, I: Gascket (teflon

or aluminum), J: Solid sample, K: Liquid sample

Fig. 7.4 Schematic diagram of apparatus used for batch experiment to examine amino acid reactions during interaction between sediments and hydrothermal solutions

The technical difficulties associated with the various flow-type experimental apparatuses are generally greater than those of batch-type apparatuses. With flow-type apparatuses it is difficult to precisely control the temperature, pressure, and flow rate of the reaction solution. Redox reaction conditions cannot be controlled or measured, and obtaining material to construct the experimental apparatus is problematic. The flow tubes in various components of flowtype systems are commonly made of stainless steel alloys (e.g., Hastelloy or Inconel) because of their resistance to corrosion, ease of handling, and low cost. We built a flowtype system with stainless steel flow tubes (described later). When artificial seawater was used in that system, it caused severe corrosion of the flow tubes and pressure gauges. If high-salinity solutions such as seawater are to be reacted in flow-type systems, the corrosion problem must be addressed. One solution to this problem is to use titanium steel for all parts of the apparatus that will be in contact with high-salinity reaction solutions. However, the low heat resistance of $\mathrm{Ti}$ steel is a disadvantage in this case. If reaction temperatures and pressures lower than $100{ }^{\circ} \mathrm{C}$ and $35 \mathrm{MPa}$ are required, the use of tubes made of polyetheretherketone (PEEK) resin may be possible, but an ideal solution for this problem is yet to be identified. The problem of corrosion was also encountered in hydrothermal experiments using artificial seawater in the reactor system for a microbial study (see Sect. 7.2). The concentrations of chemical components such as $\mathrm{Fe}, \mathrm{Ni}$, and $\mathrm{Cr}$ in SUS 316 stainless steel or Hastelloy alloy C-276 reactors increased considerably during these experiments, implying corrosion of the reactor vessels by seawater under conditions of $400{ }^{\circ} \mathrm{C}$ and $40 \mathrm{MPa}$. Further modifications, such as gold plating of the walls of the reaction vessel, are needed to reproduce the environments experienced by microbial ecosystems in deep-sea hydrothermal systems.

\subsubsection{Flow-Type Experimental System for Simulation of Water-Rock Interactions}

A flow-type experimental system (Fig. 7.5) has been installed at JAMSTEC to investigate water-rock interactions. We used the twofold (outer and inner) reaction tube of this system (Fig. 7.6) for our experiment. In this system, reaction solution is transferred from a $10 \mathrm{~L}$ plastic storage bottle into the inner tube of the reaction zone (red line on Fig. 7.5), which is made of Ti to prevent corrosion due to reaction with the solution. The outer tube surrounding the reaction tube is filled with pure water pressurized by a pump used for High Performance Liquid Chromatography (HPLC). The pressures within the outer and inner (reaction) tubes can be increased up to $100 \mathrm{MPa}$ and are manually balanced by using two back-pressure valves. The solid rock sample is placed in the center tube and the reaction solution is introduced at a maximum temperature of $500{ }^{\circ} \mathrm{C}$ and reacted with the rock sample and the cooled in a cold bath. The reacted solution is extracted via the sampling tube connected to the back pressure valve. A gas-tight syringe is used to sample the gases $\left(\mathrm{H}_{2}, \mathrm{CO}_{2}, \mathrm{CH}_{4}\right.$, and $\left.\mathrm{C}_{2} \mathrm{H}_{6}\right)$ in the reacted solution for analysis using gas chromatography. The reacted solution is also analyzed by inductively coupled plasma atomic emission spectrometry (ICP-AES) and ion chromatography for dissolved elements including $\mathrm{Na}, \mathrm{K}$, $\mathrm{Ca}$, and $\mathrm{Cl}$. Because the sensors of the pressure gauges 
Fig. 7.5 Photos of flow-type experimental system developed at JAMSTEC for simulation of water-rock interactions
Fig. 7.6 Schematic diagram of flow-type experimental system at JAMSTEC used for simulations of water-rock interactions
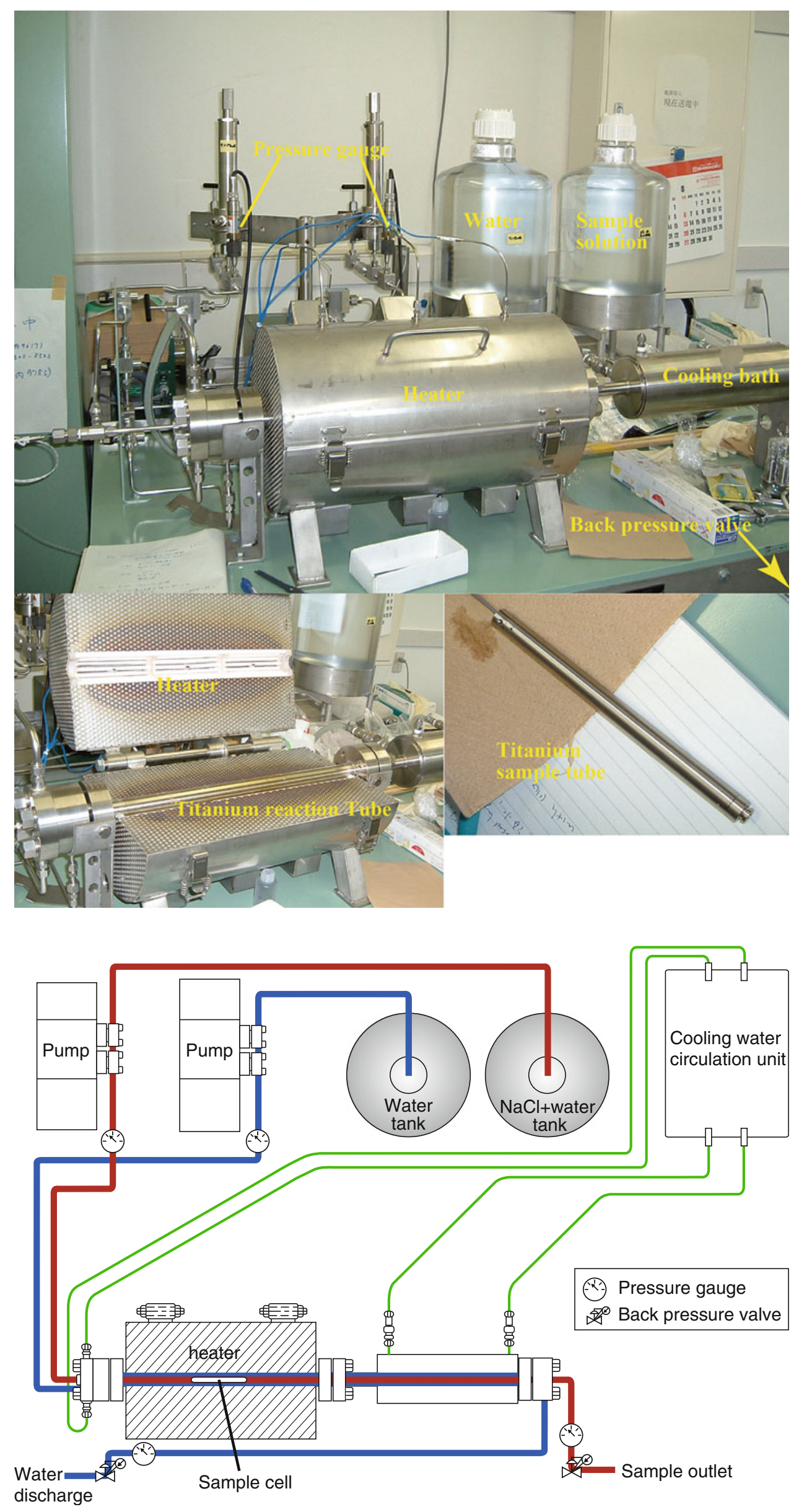
used are commonly made of easily corroded stainless steel containing $\mathrm{Cu}$, we covered the pressure sensor with a thin corrosion-resistant plate to isolate it from the reaction solution.

\subsubsection{Flow-Type Experimental System for Simulation of Microbial Ecosystems in a Deep-Sea Hydrothermal Vent System}

Our current understanding of the ecology of hydrothermal vent systems is severely limited by the difficulty of obtaining adequate quantities of samples at appropriate spatial and temporal intervals. Microbial consortia consisting mainly of Bacteria and Archaea have been found in hydrothermal deposits (such as black smoker chimneys) and close to hydrothermal systems, for example, in areas where plumes of hot hydrothermal waters mix with cold ambient seawater, and in the mixing zone below the seafloor. Both culturedependent and culture-independent approaches have provided inventories of microbial diversity at various deepsea vent fields in different geological settings (e.g., Takai et al. 2001; Reysenbach and Shock 2002; Nercessian et al. 2003; Schrenk et al. 2003; Hara et al. 2005; Nakagawa et al. 2005; Kato et al. 2009a, b, c, 2013a, b). However, these studies have provided only snapshots of dynamic microbial communities. Reproduction in the laboratory of both hydrothermal systems and their microbial communities will help us to explore the growth and metabolism of deep-sea vent microbes and to understand their role in biogeochemical processes in seafloor vent systems. Furthermore, such hydrothermal reactor systems can be used to study past hydrothermal processes, perhaps even those in extraterrestrial environments. For example, Shibuya et al. (2010) hypothesized that hydrothermal fluids in Archaean hydrothermal systems were highly alkaline. Flow-type experimental systems have a considerable advantage over batch-type systems where cultivation of microbes is required; hypotheses such as that of Shibuya et al. (2010) can be experimentally examined by simulation in a flow-type system. The fluids and precipitants so generated will provide valuable information on the Archaean ocean.

Although batch-type systems have been used to investigate interactions among microbial ecosystems, minerals, and hydrothermal solutions, flow-through devices have also been designed to study these interactions (Normand et al. 2002). Kato et al. (2013a) reported a flow-type hydrothermal reactor system that can simulate microbial and chemical processes in a deep-sea hydrothermal system. Although the reactor system has not yet been used to reproduce a microbial ecosystem, they successfully investigated the dissolution of major elements ( $\mathrm{Si}, \mathrm{Na}, \mathrm{Al}, \mathrm{K}, \mathrm{Fe}$, and $\mathrm{P}$ ) from basaltic rocks at high temperature $\left(340{ }^{\circ} \mathrm{C}\right)$ and pressure (40 MPa) under conditions of ultrapure water flow (Kato et al. 2013a). Their study was the first to demonstrate dissolution of phosphorus (a major element that is essential for life) from basaltic rocks in a flow-type hydrothermal experiment, thus providing important insights into the sustainability of microbial ecosystems in deep-sea hydrothermal systems.

Previous hydrothermal experiments (both batch- and flow-type experiments) have considered dissolution of the major elements in rocks, but not the minor elements that potentially affect the growth of microbes. Our hydrothermal experiment (described below) provides direct evidence for dissolution of $\mathrm{As}, \mathrm{Ni}, \mathrm{Zn}, \mathrm{Rb}, \mathrm{V}$, and $\mathrm{Li}$ from basaltic rocks at high temperature $\left(340{ }^{\circ} \mathrm{C}\right)$ and pressure $(40 \mathrm{MPa})$.

The hydrothermal reactor system we used has been described in detail by Kato et al. (2013a). In brief, the reactor system consists of a preheating bath $(100 \mathrm{~mL})$, a water-rock reaction bath $(390 \mathrm{~mL})$, and a cooling bath $(5 \mathrm{~L})$ (Fig. 7.7). It is a flow-through system operated by a double-plunger HPLC pump. The preheating and reaction baths are equipped with heaters that can heat them to $300{ }^{\circ} \mathrm{C}$ and $500{ }^{\circ} \mathrm{C}$, respectively. Fluid pressure inside the reactor system can reach $50 \mathrm{MPa}$ and is maintained by a back-pressure regulator. Temperatures in the preheating and the reaction baths, and pressure inside the reactor system, are continuously monitored by a computer connected to the system. The reaction bath and connected lines are made of Hastelloy alloy C-276. Other components of the system are made of SUS316 stainless steel. Cool water pumped into the cooling bath simulates the mixing of hydrothermal fluids with cool seawater. The temperature in the cooling bath is maintained at $5{ }^{\circ} \mathrm{C}$ by a cooling water jacket.

Kato et al. (2013a) reported the dissolution of major elements from basaltic rocks under the following conditions: fluid pressure of $40 \mathrm{MPa}$, preheating bath at $250{ }^{\circ} \mathrm{C}$, reaction bath at $340{ }^{\circ} \mathrm{C}$, and water flow of $6 \mathrm{~mL} / \mathrm{h}$. The reactor system was operated for 1,271 h using basalt samples and ultrapure water, and for 1,920 h without basalts (blank test). Fluid samples were collected intermittently from the cooling bath, and then analyzed by multi-channel ICP-AES (SPS5500; SII NanoTechnology, Chiba, Japan). The original concentrations of minor elements in the basalts (also determined by the ICP-AES) were V, 411 ppm; Rb, 130 ppm; Zn, 91.3 ppm; Ni, $11.1 \mathrm{ppm}$; and Li, 7.33 ppm.

The changes of concentrations of $\mathrm{As}, \mathrm{Ni}, \mathrm{Zn}, \mathrm{Rb}, \mathrm{V}$, and $\mathrm{Li}$ in the collected samples that are the same ones as those reported by Kato et al. (2013a) during the experiment are shown (Fig. 7.8). The final concentrations of these elements are clearly higher than those of the blank test, indicating that they were dissolved from the basaltic rocks during the experiment. These elements, if dissolved from basaltic rocks in deep-sea hydrothermal systems, might support the growth of microbes living there. Arsenic is used by microbes in the form of organoarsenicals, which are involved in microbial cellular functions, or as an electron acceptor 
during anaerobic respiration (Stolz et al. 2006). Nickel and $\mathrm{Zn}$ are necessary for enzymes to function as cofactors (Morel and Price 2003). Vanadium is used by some microbes as a cofactor for nitrogen-fixation enzymes (nitrogenase) (Robson et al. 1986). Lithium and $\mathrm{Rb}$ are probably not essential for life, and their effect on microbial growth is unclear.

\subsubsection{Supercritical Water Flow-Type System to Simulate Amino Acid Reactions}

To examine the possible reactions of amino acids in simulated hydrothermal systems, we constructed a supercritical water-flow reactor (SCWFR) at Yokohama National University (Fig. 7.9). The SCWFR is equipped with an infrared (IR) gold image furnace. The temperature of fluid in the reaction tube is monitored with thermocouples. We examined the polymerization of glycine and the stability of some amino acids under high temperature conditions up to and above the critical temperature for water.

The sample solution was pumped into the reaction tube with an HPLC pump. The fluid pressure was kept at $25 \mathrm{MPa}$ by a back-pressure regulator. Without preheating, the fluid was rapidly heated (within a few seconds) to $400{ }^{\circ} \mathrm{C}$ by an IR gold image furnace. The furnace was equipped with four $26.5 \mathrm{~cm}$ quartz-tungsten lamps within a gold-plated body, and radiated heat uniformly into the reaction tube. The reaction tube was made of Hastelloy alloy C-276, and connectors in the high-temperature area of the system were

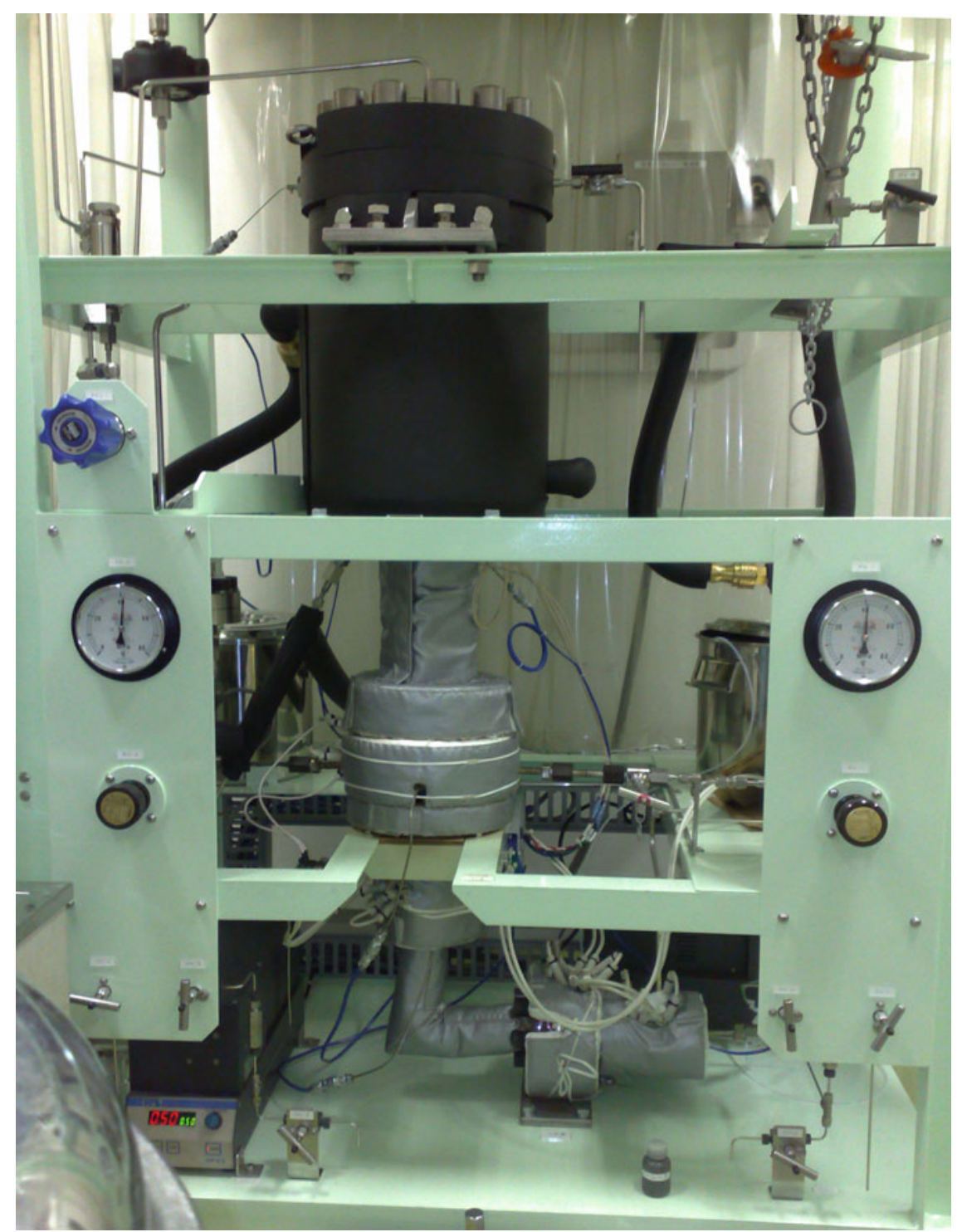

Fig. 7.7 Photo and schematic diagram of flow-type hydrothermal reactor system described previously (Kato et al. 2013a) 


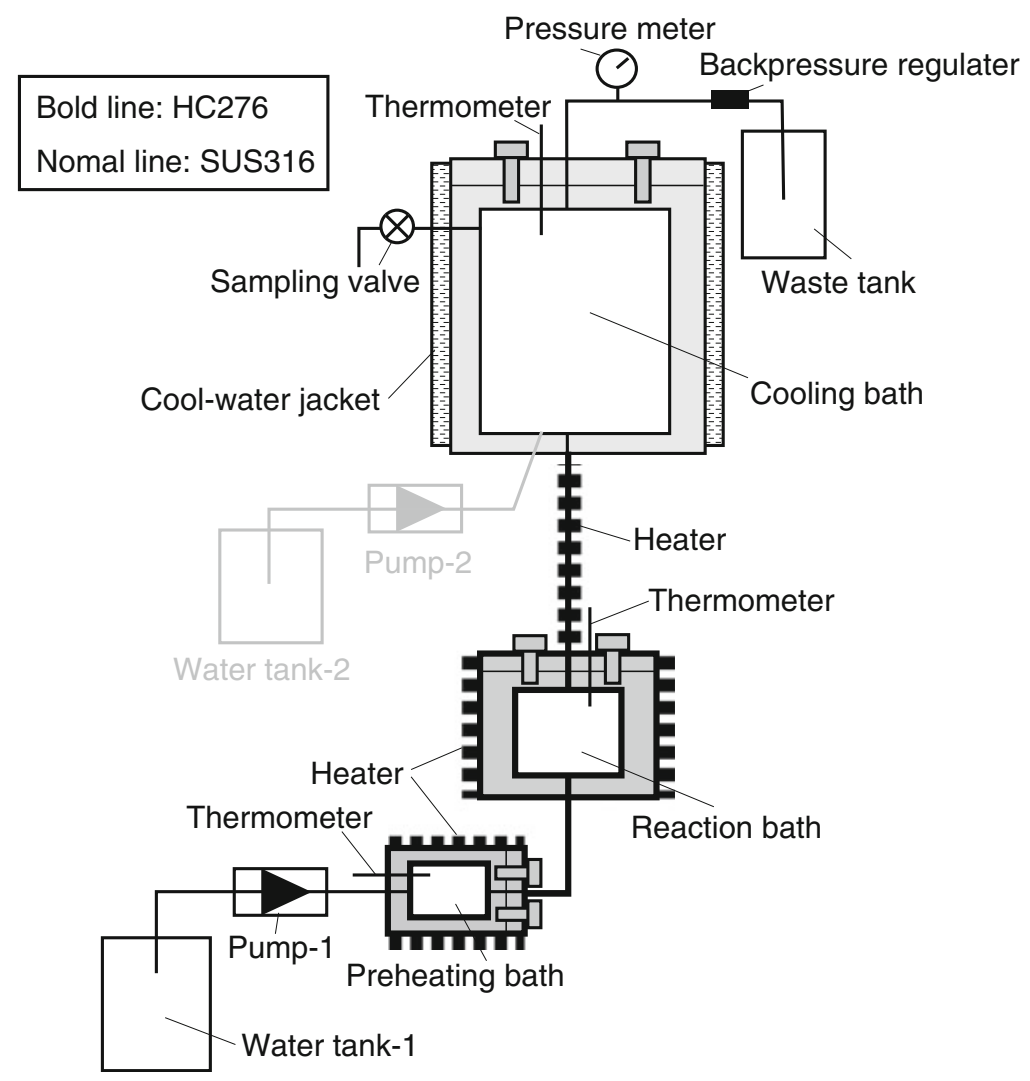

Fig. 7.7 (continued)

made of Inconel (INC-200-3). Temperatures both inside and outside the reaction tube were monitored with thermocouples. The thermocouple used to monitor fluid temperature was sheathed with Inconel.

The reactor was used to examine the formation of organic aggregates from a solution of complex organic compounds that were abiotically synthesized from a simulated primitive earth atmosphere by irradiation with high-energy protons (Kurihara et al. 2012). Under hydrothermal conditions, the structure of some of the resultant organic compounds changed, forming organic aggregates. The formation of organic aggregates such as these might have been an important step in the chemical evolution that led to the development of life on Earth. The reactor system was also used below the critical temperature of water. We tested the stability and reaction of several amino acids at $200-250{ }^{\circ} \mathrm{C}$ (Chandru et al. 2013). The resultant data showed that the survivabilities of individual amino acids in the simulators differed. We found that the stability of the amino acids was constrained by heating time, exposure time to cold quenching, and the presence and amounts of metal ions and silica (e.g., Chandru et al. 2013).

\subsection{High-Velocity Friction Apparatus for Simulation of Faulting in an Earthquake-Driven Subsurface Biosphere}

To simulate faulting, which would generate hydrogen to sustain methanogenesis, we modified a rotary-shear, highspeed friction testing apparatus at JAMSTEC to measure the physical properties of faults (Shimamoto and Tsutsumi 1994; Hirose and Shimamoto 2005). High-speed slip on a fault under normal stress is simulated in this apparatus by placing a pair of solid (or hollow) cylindrical specimens end to end and applying an axial load. Then, one specimen is kept stationary and the other rotated at high speed (Fig. 7.10). To measure the concentration of the hydrogen generated, the experiment was conducted in a pressure vessel attached to a gas chromatograph (Fig. 7.11, Hirose et al. 2011, 2012). Samples for stable isotope analysis were removed via a septum mounted on the vessel by means of a gas-tight syringe and stored in a helium-filled glass vial for later analysis by continuous-flow isotope ratio mass 
Fig. 7.8 Changes of

concentrations of As, $\mathrm{Ni}, \mathrm{Zn}, \mathrm{Rb}$, $\mathrm{V}$, and $\mathrm{Li}$ in samples taken during experiments conducted using the reactor shown in Fig. 7.7
Fig. 7.9 Schematic diagram of Supercritical Water Flow Reactor (SCWFR) developed at National Yokohama University (Islam et al. 2003). $G C$ gas cylinder, $R$, reservoir, $P$ HPLC pump, $I V$ injection valve, IRGF infrared gold image furnace, $R T$ reaction tube, $T C$ temperature controller, $T D$ temperature display, $t c l$ and $t c 2$ thermocouples, $C B$ cold bath $\left(0{ }^{\circ} \mathrm{C}\right), C J$ cooling jacket, $U T$ outlet tube, $B P R$ back pressure regulator, $S T$ sampling tube

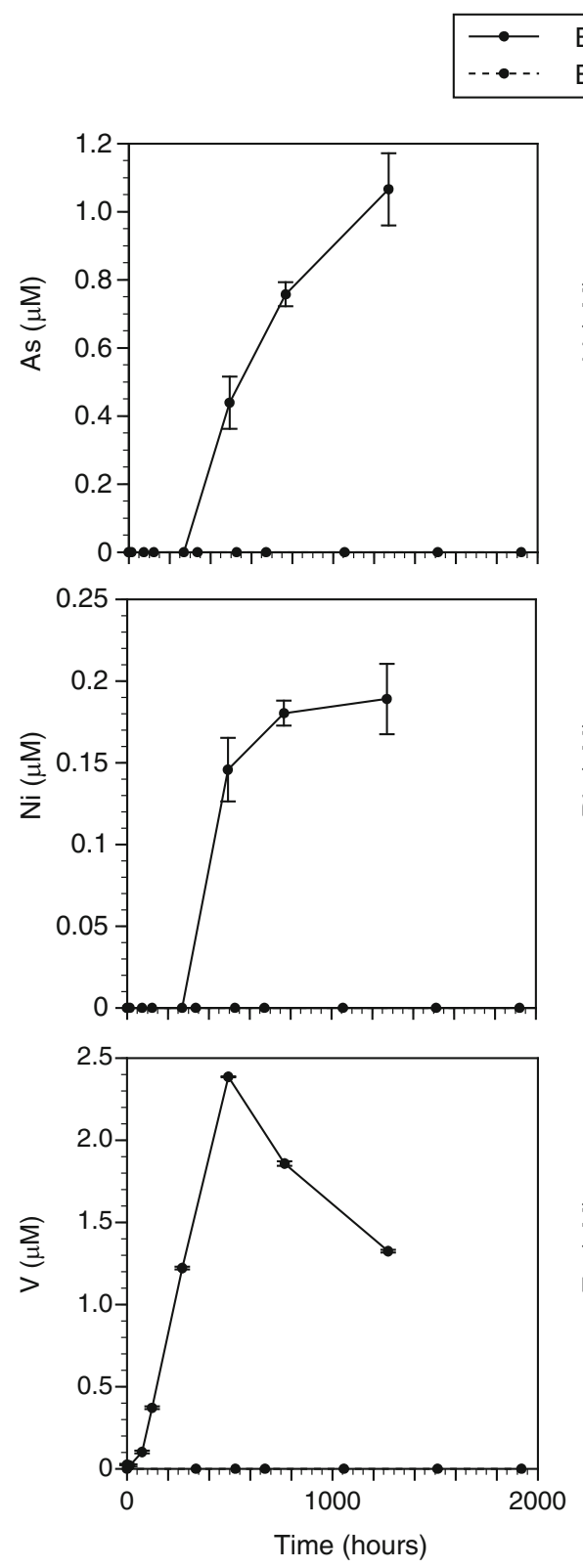

Basalts + Water

Blank
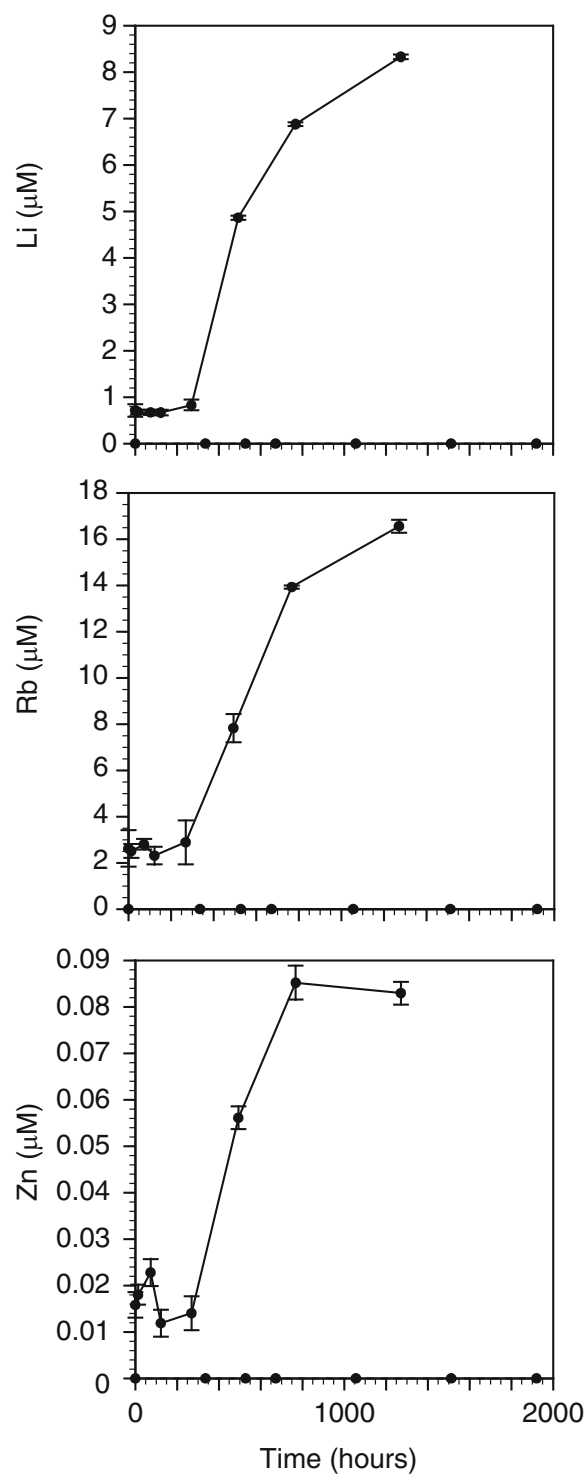

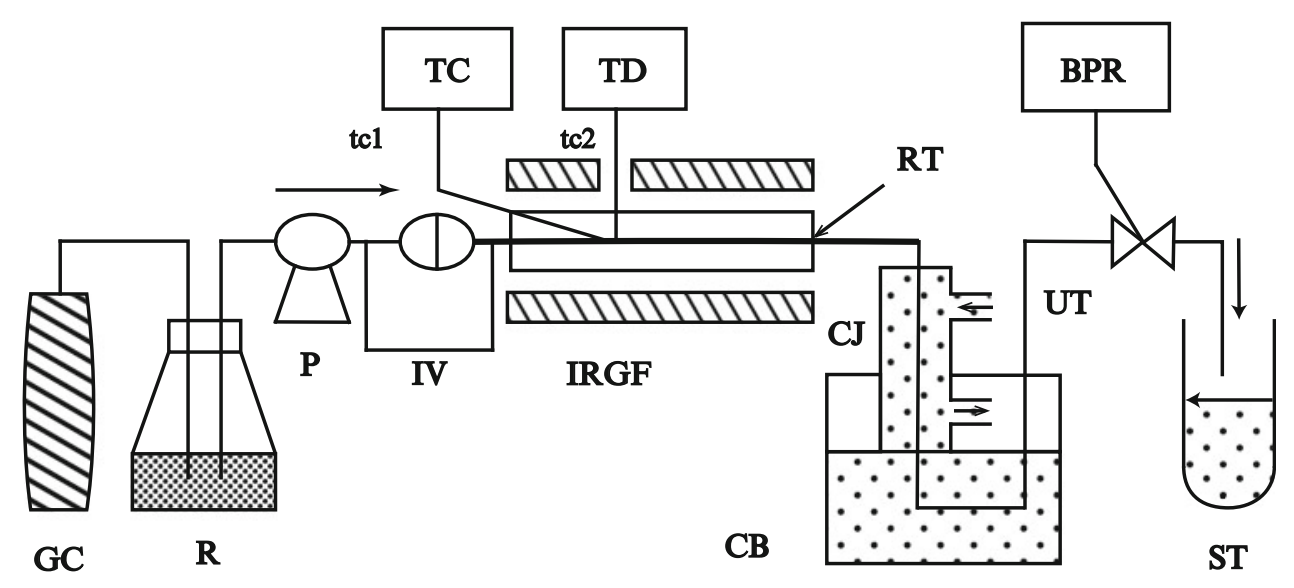


Fig. 7.10 Schematic diagrams of the rotary-shear, high-speed friction testing apparatus (Shimamoto and Tsutsumi 1994)
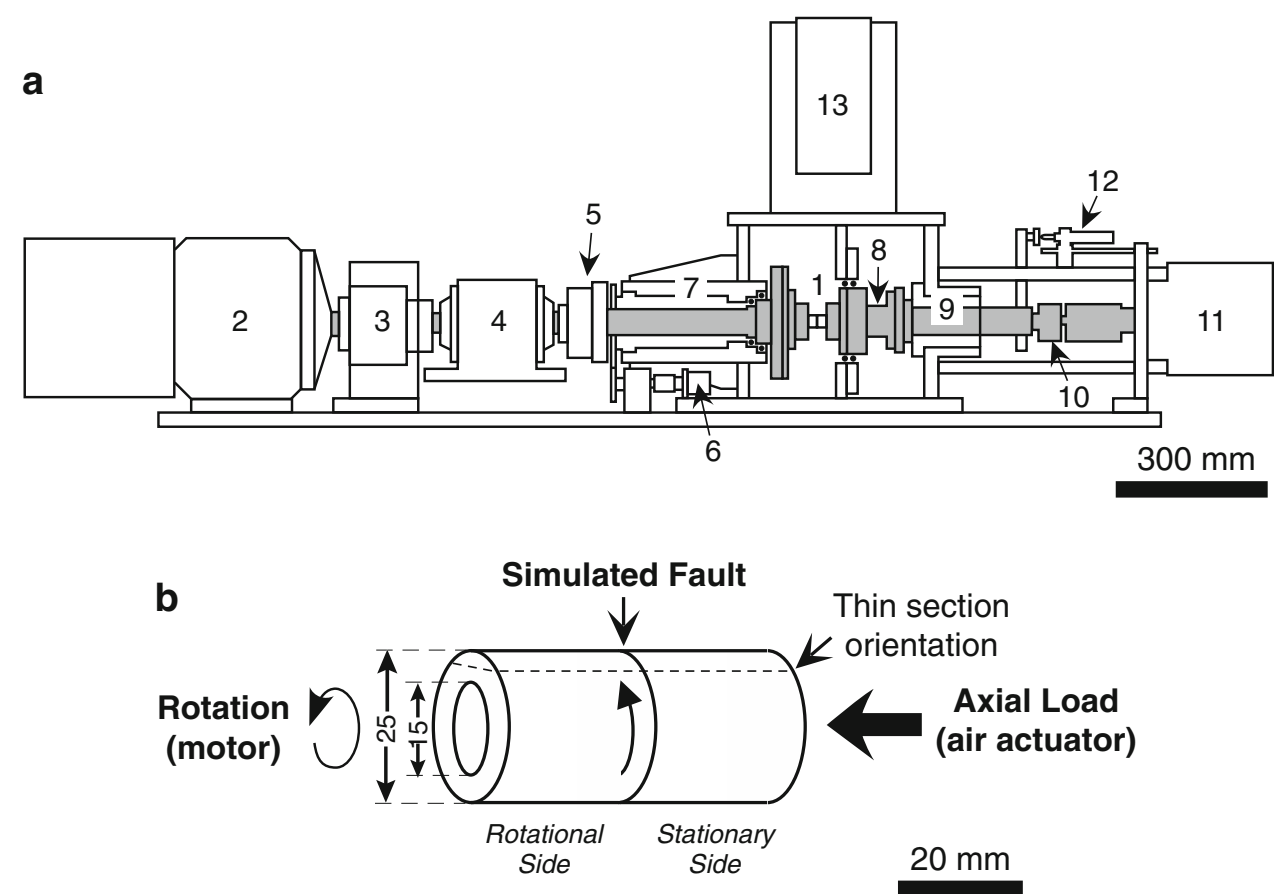

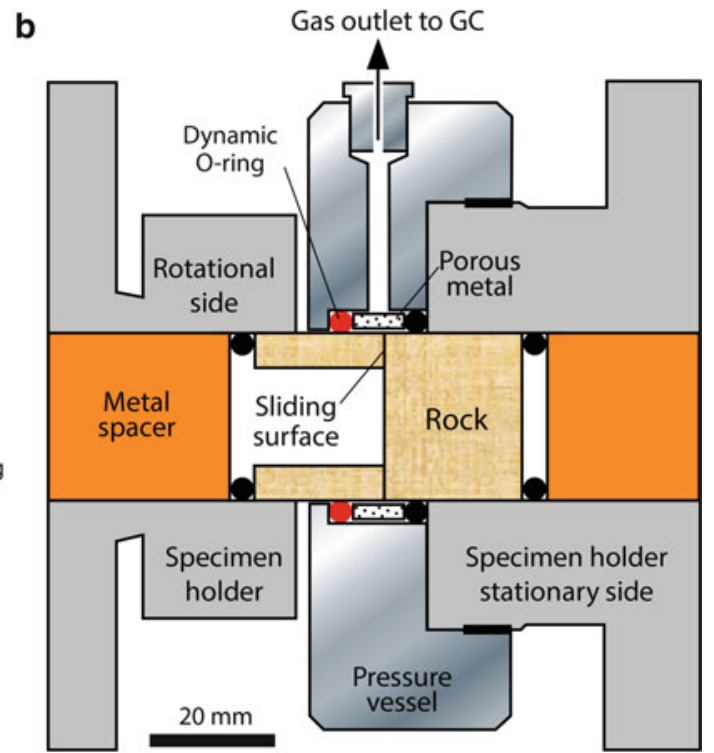

Fig. 7.11 Photo and schematic diagram of pressure vessel equipped with the friction experiment system (Hirose et al. 2011)

spectrometry (Kawagucci et al. 2010). The pressure vessel was filled with air at a room humidity of $\sim 45 \%$ for most of the experiments, but for some experimental runs air was replaced with argon gas to replicate the nominally anoxic conditions under which earthquakes normally occur.

For our experiments, we used typical rock types of the Earth's crust, such as basalt, dunite, granite, marble, and sandstone. The sliding surfaces of the specimens were first ground and roughened with 100 grit $\mathrm{SiC}$ powder. They were then either dried in an oven at $100^{\circ} \mathrm{C}$ for at least two weeks, or saturated with distilled water in a vacuum chamber. Sliding was at a constant velocity of $1.6 \mathrm{~m} / \mathrm{s}$ under a normal stress of 0.5-2.5 MPa for a total displacement of $10 \mathrm{~m}$. The $\mathrm{H}_{2}$ released was measured by a vessel-mounted gas chromatograph with a thermal conductivity detector. The $\mathrm{H}_{2} \mathrm{O}$ used to wet the specimens and the $\mathrm{H}_{2}$ released from the wet-basalt specimen were also sampled for stable isotope analyses. We found that abundant $\mathrm{H}_{2}$ was produced during the friction experiments and that the amounts of $\mathrm{H}_{2}$ produced were proportional to the frictional work done (Hirose et al. 2011, 2012). 
Friction at a dynamic O-ring seal (Teflon-containing Oring: Product No. TOMBO No.2670-FA-F) used in the reaction vessel to confine the released gas during rapid sliding (Fig. 7.11, Hirose et al. 2011) contributed to the measured shear traction. Therefore, to determine accurately the frictional work acting on the fault, the mechanical data must be corrected. To evaluate the friction at the contact between the O-ring and the outer surface of the rock, we opened a 1-mm-wide space between the rotational and stationary specimens and then measured the shear traction due to O-ring friction only. This experiment was conducted for all of the rock types we used under the same conditions as the primary experiments, except that no normal load was applied. We found that frictional behavior was independent of rock type. For an applied normal stress of $1 \mathrm{MPa}$, O-ring friction contributed $\sim 18 \%$ to the initial peak and $<8 \%$ to the steady-state measured shear traction. To account for this contribution, we simply subtracted the shear traction determined in the supplementary experiments from the raw traction data for each experiment.

Hydrogen was also released from the O-ring as a result of abrasive wear and frictional heat during sliding. We measured the concentration of $\mathrm{H}_{2}$ gas generated only from the O-ring in all blank experiments by again opening a 1-mm-wide space between the rotational and stationary specimens and then measuring the $\mathrm{H}_{2}$ gas generated. The $\mathrm{H}_{2}$ gas concentration from the O-ring varied from 50 to $195 \mathrm{ppm}$, depending on the initial surface roughness of the outer surfaces of the specimens and on their outer diameter. Thus, we determined the amount of $\mathrm{H}_{2}$ generated by faulting alone by simply subtracting $150 \mathrm{ppm}$ from the raw data from each experiment (Hirose et al. 2011). The O-ring contribution of $150 \mathrm{ppm}$ corresponds to between $4 \%$ and $35 \%$ of the measured $\mathrm{H}_{2}$ during the experiments described by Hirose et al. (2011). The $\mathrm{H}_{2}$ generated from the O-ring might be a function of shear displacement. However, because we used a displacement of $10 \mathrm{~m}$ in all experiments, this was not an important issue.

Acknowledgments We thank Mamiko Umetsu and Sayuri Kubo for drawing some figures. The comments by Yoshinori Takano and Fumitaka Yanagisawa considerably improved our manuscript. This study was supported by MEXT, Grant-in-Aid for Scientific Research on Innovative Areas "Project TAIGA: Trans-crustal Advection and Insitu biogeochemical process of Global sub-seafloor Aquifer". Authors wish to thank Prof. Urabe and members of Project TAIGA for their collaboration and discussion.

Open Access This chapter is distributed under the terms of the Creative Commons Attribution Noncommercial License, which permits any noncommercial use, distribution, and reproduction in any medium, provided the original author(s) and source are credited.

\section{References}

Alt JC (1995) Sulfur isotopic profile through the oceanic crust: sulfur mobility and seawater-crustal sulfur exchange during hydrothermal alteration. Geology 23:585-588

Barnes HL (1963) Ore solution chemistry. I. Experimental determination of mineral solubilities. Econ Geol 58:1054-1060

Barnes HL (1971) Investigation in hydrothermal sulfide systems. In: Ulmer GC (ed) Research Techniques for High Pressure and High Temperature. Springer-Verlag, Berlin Heidelberg, pp 317-335

Barnes HL, Gould WW (1992) Hydrothermal replacement of carbonates by sulfides. Paper presented at 7 th international symposium on water-rock interaction Balkema, Utah, 13-18 July 1992

Barnes I, Rapp JB, O’Neill JR, Sheppard RA, Gude AJ (1972) Metamorphic assemblages and the direction of flow of metamorphic fluids in four instances of serpentinization. Contrib Mineral Petrol 35:263-276

Barnes HL, Downs WF, Rimstidt JD (1983) Experimental determination of rates of hydrothermal reactions. Paper presented at the 1st international symposium on hydrothermal reactions, Tokyo Institute of Technology, Tokyo

Berndt ME, Allen DE, Seyfried WE (1996) Reduction of $\mathrm{CO}_{2}$ during serpentinization of olivine at $300^{\circ} \mathrm{C}$ and 500 bar. Geology 24:351-354

Bridgeman PW (1949) The physics of high pressure. Bell and Sons, London, $445 \mathrm{pp}$

Chandru K, Imai E, Kaneko T, Obayashi Y, Kobayashi K (2013) Survivability and Abiotic Reactions of Selected Amino Acids in Different Hydrothermal System Simulators. Origins Life Evol Biospheres 43:99-108. doi:10.1007/s11084-013-9330-9

Charles RW, Bayhurst GK (1983) Rock-fluid interactions in a temperature gradient: biotite granodiorite $+\mathrm{H}_{2} \mathrm{O}$. J Volcanol Geotherm Res 15:137-166. doi:10.1016/0377-0273(83)90098-7

Corliss JB, Dymond J, Gordon LI, Edmond JM, Herzen RPV, Ballard RD, Green K, Williams D, Bainbridge A, Crane K, Vanandel TH (1979) Submarine thermal springs on the Galapagos Rift. Science 203:1073-1083. doi:10.1126/science.203.4385.1073

Cowen JP, Giovannoni SJ, Kenig F, Johnson HP, Butterfield D, Rappe MS, Hutnak M, Lam P (2003) Fluids from aging ocean crust that support microbial life. Science 299:120-123. doi:10.1126/science. 1075653

Dickson FW, Blount CW, Tunell G (1963) Use of hydrothermal solution equipment to determine the solubility of anhydrite in water from $100^{\circ} \mathrm{C}$ to $275^{\circ} \mathrm{C}$ and from 1 bar to 1000 bars. Am J Sci 261:61-78

Gallant RM, Von Damm KL (2006) Geochemical controls on hydrothermal fluids from the Kairei and Edmond Vent Fields, $23^{\circ}-25^{\circ} \mathrm{S}$, Central Indian Ridge. Geochem Geophys Geosyst 7. doi:10.1029/ $2005 \mathrm{gc} 001067$

Gold T (1992) The deep, hot biosphere. Proc Natl Acad Sci U S A 89:6045-6049

Hara K, Kakegawa T, Yamashiro K, Maruyama A, Ishibashi JI, Marumo K, Urabe T, Yamagishi A (2005) Analysis of the archaeal sub-seafloor community at Suiyo Seamount on the Izu-Bonin Arc. Space Life Sci Closed Ecol Syst Earth Space Appl 35:1634-1642. doi:10.1016/j.asr.2005.04.111

Higashi Y, Sunamura M, Kitamura K, Nakamura K, Kurusu Y, Ishibashi J, Urabe T, Maruyama A (2004) Microbial diversity in hydrothermal surface to subsurface environments of Suiyo Seamount, Izu-Bonin Arc, using a catheter-type in situ growth chamber. Fems Microbiol Ecol 47:327-336. doi:10.1016/s0168-6496( 04)00004-2 
Hirose T, Shimamoto T (2005) Growth of molten zone as a mechanism of slip weakening of simulated faults in gabbro during frictional melting. J Geophys Res Solid Earth 110. doi:10.1029/ 2004jb003207

Hirose T, Kawagucci S, Suzuki K (2011) Mechanoradical $\mathrm{H}_{2}$ generation during simulated faulting: implications for an earthquakedriven subsurface biosphere. Geophys Res Lett 38. doi:10.1029/ $2011 \mathrm{gl} 048850$

Hirose T, Kawagucci S, Suzuki K (2012) Correction to "Mechanoradical $\mathrm{H}_{2}$ generation during simulated faulting: Implications for an earthquake-driven subsurface biosphere". Geophys Res Lett 39:L23304. doi:10.1029/2012GL054539

Huber AB, Kania A, Tran TS, Gu CH, Garcia ND, Lieberam I, Johnson D, Jessel TM, Ginty DD, Kolodkin AL (2006) Distinct roles for secreted semaphorin signaling in spinal motor axon guidance. Neuron 49:319. doi:10.1016/j.neuron.2006.01.002

Islam Md. N, Kaneko T, Kobayashi K (2003) Reaction of amino acids in a supercritical water-flow reactor simulating submarine hydrothermal systems. Bull Chem Soc Jpn 76:1171-1178

Ito M, Gupta LP, Masuda H, Kawahata H (2006) Thermal stability of amino acids in seafloor sediment in aqueous solution at high temperature. Org Geochem 37:177-188. doi:10.1016/j.orggeochem. 2005.09.004

Ito M, Yamaoka K, Masuda H, Kawahata H, Gupta LP (2009) Thermal stability of amino acids in biogenic sediments and aqueous solutions at seafloor hydrothermal temperatures. Geochem J 43:331-341

Kato S, Kobayashi C, Kakegawa T, Yamagishi A (2009a) Microbial communities in iron-silica-rich microbial mats at deep-sea hydrothermal fields of the Southern Mariana Trough. Environ Microbiol 11:2094-2111. doi:10.1111/j.1462-2920.2009.01930.x

Kato S, Hara K, Kasai H, Teramura T, Sunamura M, Ishibashi J-I, Kakegawa T, Yamanaka T, Kimura H, Marumo K, Urabe T, Yamagishi A (2009b) Spatial distribution, diversity and composition of bacterial communities in sub-seafloor fluids at a deep-sea hydrothermal field of the Suiyo Seamount. Deep Sea Res Part I Oceanogr Res Papers 56:1844-1855. doi:10.1016/j.dsr.2009.05.004

Kato S, Yanagawa K, Sunamura M, Takano Y, Ishibashi J-I, Kakegawa T, Utsumi M, Yamanaka T, Toki T, Noguchi T, Kobayashi K, Moroi A, Kimura H, Kawarabayasi Y, Marumo K, Urabe T, Yamagishi A (2009c) Abundance of Zetaproteobacteria within crustal fluids in back-arc hydrothermal fields of the Southern Mariana Trough. Environ Microbiol 11:3210-3222. doi:10.1111/j. 1462-2920.2009.02031.x

Kato S, Shibuya T, Nakamura K, Suzuki K, Rejishkumar VJ, Yamagishi A (2013a) Elemental dissolution of basalts with ultrapure water at $340^{\circ} \mathrm{C}$ and $40 \mathrm{MPa}$ in a newly developed flow-type hydrothermal apparatus. Geochem J 47:89-92

Kato S, Nakawake M, Kita J, Yamanaka T, Utsumi M, Okamura K, Ishibashi J-I, Ohkuma M, Yamagishi A (2013b) Characteristics of microbial communities in crustal fluids in a deep-sea hydrothermal field of the Suiyo seamount. Front Microbiol 4:85. doi:10.3389/ fmicb.2013.00085

Kawagucci S, Toki T, Ishibashi J, Takai K, Ito M, Oomori T, Gamo T (2010) Isotopic variation of molecular hydrogen in $20-375^{\circ} \mathrm{C}$ hydrothermal fluids as detected by a new analytical method. J Geophys Res 115, G03021. doi:10.1029/2009JG001203

Kelley DS, Karson JA, Fruh-Green GL, Yoerger DR, Shank TM, Butterfield DA, Hayes JM, Schrenk MO, Olson EJ, Proskurowski G, Jakuba M, Bradley A, Larson B, Ludwig K, Glickson D, Buckman K, Bradley AS, Brazelton WJ, Roe K, Elend MJ, Delacour A, Bernasconi SM, Lilley MD, Baross JA, Summons RT, Sylva SP (2005) A serpentinite-hosted ecosystem: the lost city hydrothermal field. Science 307:1428-1434. doi:10.1126/sci ence. 1102556
Kimura H, Asada R, Masta A, Naganuma T (2003) Distribution of microorganisms in the subsurface of the manus basin hydrothermal vent field in Papua new guinea. Appl Environ Microbiol 69:644-648. doi:10.1128/aem.69.1.644-648.2003

Kumagai H, Nakamura K, Toki T, Morishita T, Okino K, Ishibashi JI, Tsunogai U, Kawagucci S, Gamo T, Shibuya T, Sawaguchi T, Neo N, Joshima M, Sato T, Takai K (2008) Geological background of the Kairei and Edmond hydrothermal fields along the Central Indian Ridge: implications of their vent fluids' distinct chemistry. Geofluids 8:239-251. doi:10.1111/j.1468-8123.2008.00223.x

Kurihara H, Yabuta H, Kaneko T, Obayashi Y, Takano Y, Kobayashi K (2012) Characterization of organic aggregates formed by heating products of simulated Primitive Earth atmosphere experiments. Chem Lett 41:441-443. doi:10.1246/cl.2012.441

McCollom TM, Seewald JS (2001) A reassessment of the potential for reduction of dissolved $\mathrm{CO}_{2}$ to hydrocarbons during serpentinization of olivine. Geochim Cosmochim Acta 65:3769-3778. doi:10.1016/ s0016-7037(01)00655-x

McCollom TM, Seewald JS (2003a) Experimental constraints on the hydrothermal reactivity of organic acids and acid anions: I. Formic acid and formate. Geochim Cosmochim Acta 67:3625-3644. doi:10.1016/s0016-7037(03)00136-4

McCollom TM, Seewald JS (2003b) Experimental study of the hydrothermal reactivity of organic acids and acid anions: II. Acetic acid, acetate, and valeric acid. Geochim Cosmochim Acta 67:3645-3664. doi:10.1016/s0016-7037(03)00135-2

McCollom TM, Seewald JS (2007) Abiotic synthesis of organic compounds in deep-sea hydrothermal environments. Chem Rev 107:382-401. doi:10.1021/cr0503660

Morel FMM, Price NM (2003) The biogeochemical cycles of trace metals in the oceans. Science 300:944-947. doi:10.1126/science. 1083545

Morey GW (1942) Solubility of solids in water vapor. Proc Am Soc Testing Mater 42:980-988

Morey GW, Chen WT (1955) The action of hot water on some feldspars. Am Mineral 40:996-1000

Morey GW, Fournier RO (1961) The decomposition of microcline, albite, and nepheline in hot water. Am Mineral 46:688-699

Morey GW, Hesselgesser JM (1951) The solubility of some minerals in superheated steam at higher pressures. Econ Geol 46:821-835

Morey GW, Ingerson E (1937) The pneumatolytic and hydrothermal alteration and synthesis of silicates. Econ Geol 32:607-761

Nakagawa T, Ishibashi JI, Maruyama A, Yamanaka T, Morimoto Y, Kimura H, Urabe T, Fukui M (2004) Analysis of dissimilatory sulfite reductase and 16S rRNA gene fragments from deep-sea hydrothermal sites of the Suiyo Seamount, Izu-Bonin Arc, Western Pacific. Appl Environ Microbiol 70:393-403. doi:10.1128/aem.70. $1.393-403.2004$

Nakagawa S, Inagaki F, Takai K, Horikoshi K, Sako Y (2005) Thioreductor micantisoli gen. nov., sp nov., a novel mesophilic, sulfur-reducing chemolithoautotroph within the epsilonProteobacteria isolated from hydrothermal sediments in the MidOkinawa Trough. Int J Syst Evol Microbiol 55:599-605. doi:10. 1099/ijs.0.63351-0

Nealson KH, Inagaki F, Takai K (2005) Hydrogen-driven subsurface lithoautotrophic microbial ecosystems (SLiMEs): do they exist and why should we care? Trends Microbiol 13:405-410. doi:10.1016/j. tim.2005.07.010

Nercessian O, Reysenbach AL, Prieur D, Jeanthon C (2003) Archaeal diversity associated with in situ samplers deployed on hydrothermal vents on the East Pacific Rise $\left(13^{\circ} \mathrm{N}\right)$. Environ Microbiol 5:492-502. doi:10.1046/j.1462-2920.2003.00437.x

Normand C, Williams-Jones AE, Martin RF, Vali H (2002) Hydrothermal alteration of olivine in a flow-through autoclave: nucleation and growth of serpentine phases. Am Mineral 87:1699-1709 
Reysenbach AL, Shock E (2002) Merging genomes with geochemistry in hydrothermal ecosystems. Science 296:1077-1082. doi:10.1126/ science. 1072483

Robson RL, Eady RR, Richardson TH, Miller RW, Hawkins M, Postgate JR (1986) The alternative nitrogenase of AzotobacterChroococcum is a vanadium enzyme. Nature 322:388-390. doi: $10.1038 / 322388 \mathrm{a} 0$

Russell MJ, Hall AJ (1997) The emergence of life from iron monosulphide bubbles at a submarine hydrothermal redox and $\mathrm{pH}$ front. J Geol Soc 154:377-402. doi:10.1144/gsjgs.154.3.0377

Rytuba JJ, Potter JM, Dickson FW, Radtke AS (1978) Experimental alteration of rhyolite glass at $300^{\circ} \mathrm{C}$ : Implication for silicate mineral zoning in modermitt mercury deposit, Nevada. Trans Am Geophys Union 59:1221

Schrenk MO, Kelley DS, Delaney JR, Baross JA (2003) Incidence and diversity of microorganisms within the walls of an active deep-sea sulfide chimney. Appl Environ Microbiol 69:3580-3592. doi:10. 1128/aem.69.6.3580-3592.2003

Seewald JS (1994) Evidence for metastable equilibrium between hydrocarbons under hydrothermal conditions. Nature 370:285-287. doi:10.1038/370285a0

Sénarmont HD (1851) Expérience sur la formation des minéraux par voie humide dans les gîtes métallifères concrétionnés. Annales de Chimie et Physique, Troisième Séries 129-175

Seweeton FH, Baes CF Jr (1970) The solubility of magnetite and hydrolysis of ferrous ion in aqueous solutions at elevated temperatures. J Chem Thermodyn 2:479-500

Seyfried WE Jr (1987) Experimental and theoretical constraints on hydrothermal alteration processes at midocean ridges. Annu Rev Earth Planet Sci 15:317-335. doi:10.1146/annurev.ea.15.050187. 001533

Seyfried WE Jr, Ding K (1993) The effect of redox on the relative solubilities of copper and iron in Cl-bearing aqueous fluids at elevated-temperatures and pressures: an exprimental study with application to subseafloor hydrothermal systems. Geochim Cosmochim Acta 57:1905-1917. doi:10.1016/0016-7037(93)90083-9

Seyfried WE Jr, Gordon PC, Dickson FW (1979) New reaction cell for hydrothermal solution equipment. Am Mineral 64:646-649

Seyfried WE Jr, Chen X, Chan LH (1998) Trace element mobility and lithium isotope exchange during hydrothermal alteration of seafloor weathered basalt: An experimental study at $350^{\circ} \mathrm{C}, 500$ bars. Geochim Cosmochim Acta 62:949-960. doi:10.1016/s0016-7037( 98)00045-3

Seyfried WE Jr, Foustoukos DI, Fu Q (2007) Redox evolution and mass transfer during serpentinization: an experimental and theoretical study at $200^{\circ} \mathrm{C}, 500$ bar with implications for ultramafic-hosted hydrothermal systems at Mid-Ocean Ridges. Geochim Cosmochim Acta 71:3872-3886. doi:10.1016/j.gca.2007.05.015

Shibuya T, Komiya T, Nakamura K, Takai K, Maruyama S (2010) Highly alkaline, high-temperature hydrothermal fluid generated by Archean $\mathrm{CO}_{2}$-rich seawater. Geochim Cosmochim Acta 74: A951

Shibuya T, Yoshizaki M, Masaki Y, Suzuki K, Takai K, Russell MJ (2013) Reactions between basalt and $\mathrm{CO}_{2}$-rich seawater at 250 and $350^{\circ} \mathrm{C}, 500$ bars: Implications for the $\mathrm{CO}_{2}$ sequestration into the modern oceanic crust and the composition of hydrothermal vent fluid in the $\mathrm{CO}_{2}$-rich early ocean. Chem Geol 359:1-9. doi:10. 1016/j.chemgeo.2013.08.044

Shimamoto T, Tsutsumi A (1994) A new rotary-shear high-velocity frictional testing machine: its basic design and scope of research (in Japanese with English abstract). Struct Geol 39:65-78

Spiess FN, Macdonald KC, Atwater T, Ballard R, Carranza A, Cordoba D, Cox C, Diazgarcia VM, Francheteau J, Guerrero J, Hawkins J, Haymon R, Hessler R, Juteau T, Kastner M, Larson R, Luyendyk B, Macdougall JD, Miller S, Normark W, Orcutt J, Rangin C (1980) East Pacific rise: hot springs and geophysical experiments. Science 207:1421-1433. doi:10.1126/science.207.4438.1421

Stolz JF, Basu P, Santini JM, Oremland RS (2006) Arsenic and selenium in microbial metabolism. Annu Rev Microbiol 60:107-130. doi:10.1146/annurev.micro.60.080805.142053

Takai K, Komatsu T, Inagaki F, Horikoshi K (2001) Distribution of archaea in a black smoker chimney structure. Appl Environ Microbiol 67:3618-3629. doi:10.1128/aem.67.8.3618-3629.2001

Takai K, Gamo T, Tsunogai U, Nakayama N, Hirayama H, Nealson KH, Horikoshi K (2004) Geochemical and microbiological evidence for a hydrogen-based, hyperthermophilic subsurface lithoautotrophic microbial ecosystem (HyperSLiME) beneath an active deep-sea hydrothermal field. Extremophiles 8:269-282. doi:10.1007/s00792-004-0386-3

Takai K, Nakamura K, Suzuki K, Inagaki F, Nealson KH, Kumagai H (2006) Ultramafics-Hydrothermalism-Hydrogenesis-HyperSLiME $\left(\mathrm{UltraH}^{3}\right)$ linkage: a key insight into early microbial ecosystem in the Archean deep-sea hydrothermal systems. Paleontol Res 10:269-282

Thornton EC, Seyfried WE (1987) Reactivity of organic-rich sediment in seawater at $350^{\circ} \mathrm{C}, 500$ bars: Experimental and theoretical constraints and implications for the Guaymas Basin hydrothermal system. Geochim Cosmochim Acta 51:1997-2010. doi:10.1016/ 0016-7037(87)90188-8

Tremaine PR, Leblanc JC (1980) The solubility of nickel oxide and hydrolysis of $\mathrm{Ni}^{2+}$ in water to $573 \mathrm{~K}$. J Chem Thermodyn 12:521-538. doi:10.1016/0021-9614(80)90182-2

Tremaine PR, Chen JD, Wallace GJ, Boivin WA (1981) Solubility of uranium (IV) oxide in alkaline aqueous solutions to $300^{\circ} \mathrm{C}$. J Solut Chem 10:221-230. doi:10.1007/bf00653099

Tuttle OF (1948) A new hydrothermal quenching apparatus. Am J Sci 246:628-635

Tuttle OF (1949) Two pressure vessels for silicate-water studies. Geol Soc Am Bull 60:1727-1729

Williams-Jones AE, Wood SA, Mountain BW, Gammons CH (eds) (1994) Experimental water-rock interaction: Applications to ore-forming hydrothermal systems. St. John's, Newfoundland, pp 131-160

Yanagawa H, Kojima K (1985) Thermophilic microspheres of peptidelike polymers and silicates formed at $250^{\circ} \mathrm{C}$. J Biochem 97:1521-1524

Yoshizaki M, Shibuya T, Suzuki K, Shimizu K, Nakamura K, Takai K, Omori S, Maruyama S (2009) $\mathrm{H}_{2}$ generation by experimental hydrothermal alteration of komatiitic glass at $300^{\circ} \mathrm{C}$ and 500 bars: a preliminary result from on-going experiment. Geochemical Journal 43:E17-E22

Zielinski RA (1979) Uranium mobility during interaction of rhyolitic obsidian, perlite, and felite with alkaline carbonate solution: $\mathrm{T}=120^{\circ} \mathrm{C}, \mathrm{P}=210 \mathrm{~kg} / \mathrm{cm}^{2}$. Chem Geol 27:47-63 